\title{
ANALISIS IMPLIKATUR PERCAKAPAN PADA MASYARAKAT DESA SERBA JADI, SUMATERA UTARA
}

\author{
Rizky Fadila ${ }^{{ }^{*}}$ \\ Joko Hariadi ${ }^{2}$ \\ Muhammad Taufik Hidayat ${ }^{3}$ \\ ${ }^{1}$ Program Studi Pendidikan Bahasa Indonesia Universitas Samudra \\ ${ }^{2}$ Program Studi Pendidikan Bahasa Indonesia Universitas Samudra \\ ${ }^{3}$ Program Studi Pendidikan Bahasa Indonesia Universitas Samudra \\ Rizkyfadila789@gmail.com*
}

\begin{abstract}
This research is entitled "Analysis of Conversational Implicatures in Serba Jadi Village Community, North Sumatra." The purpose of this study is to describe the types of implicatures in the conversations of the people of Serba Jadi Village, North Sumatra. This research is a qualitative research using a descriptive approach. The method used in this study is a qualitative descriptive method. The data that has been found is then concluded. The source of the data in this study is the conversation with the people of Serba Jadi Village, North Sumatra, which is also the subject of this research. Furthermore, the object of this research is the conversational implicatures found in the conversations of the people of Serba Jadi Village, North Sumatra. The data collection technique used in this study is the technique of recording, listening and taking notes. The analysis technique used in this study is divided into three stages including: (1) reducing the data in the form of data that has been obtained then selecting the data, then summarizing the data and classifying the data obtained for selection, (2) presenting the data with the aim that the implicatures that have been previously selected can be neatly arranged, (3) drawing conclusions from the forms of implicatures that have been previously selected are grouped and then described. The results of the research on conversational implicature analysis in the Serba Jadi Village community, North Sumatra, there are two types of implicatures in the form of conventional implicatures and also nonconventional implicatures. The results showed that the overall data obtained were forty-two data consisting of nineteen conventional implicatures, while twentythree nonconventional implicatures.
\end{abstract}

Keywords:

Implicature, Public Consersation, Sumatera Utara

\begin{abstract}
Abstrak
Penelitian ini berjudul "Analisis Implikatur Percakapan Pada Masyarakat Desa Serba Jadi, Sumatera Utara." Tujuan dalam penelitian ini adalah mendeskripsikan jenis implikatur dalam percakapan masyarakat Desa Serba Jadi, Sumatera Utara. Penelitian ini merupakan penelitian kualitatif dengan menggunakan pendekatan dekskriptif. Metode yang digunakan dalam penelitian ini adalah metode deksriptif kualitatif. Data yang sudah ditemukan kemudian disimpulkan. Sumber data dalam penelitian ini ialah percakapan pada masyarakat Desa Serba Jadi, Sumatera Utara dan sekaligus menjadi subjek dalam penelitian ini. Selanjutnya objek dalam penelitian ini yaitu implikatur percakapan yang terdapat pada percakapan masyarakat Desa Serba Jadi, Sumatera Utara. Teknik pengumpulan data yang
\end{abstract}


digunakan dalam penelitian ini adalah teknik rekam, simak dan catat. Adapun teknik analisis yang digunakan dalam penelitian ini terbagi ke dalam tiga tahapan diantaranya yaitu: (1) melakukan reduksi data berupa data yang telah diperoleh kemudian dilakukan pemilihan data, kemudian dilakukan peringkasan data dan menggolonggkan data yang didapat untuk diseleksi, (2) melakukan penyajian data dengan tujuan agar implikatur yang sudah diseleksi sebelumnya bisa tersusun rapi, (3) penarikan kesimpulan dari bentuk-bentuk implikatur yang telah diseleksi sebelumnya dikelompokkan dan kemudian akan dijabarkan. Hasil penelitian analisis implikatur percakapan pada masyarakat Desa Serba Jadi, Sumatera Utara terdapat dua jenis implikatur berupa implikatur konvensional dan juga implikatur nonkonvensional. Hasil penelitian menunjukkan data keseluruhan yang diperoleh berjumlah empat puluh dua data yang terdiri atas implikatur konvensional sebanyak Sembilan belas data, sedangkan implikatur nonkonvensional sebanyak dua puluh tiga data.

Kata Kunci:

Implikatur, Percakapan Masyarakat, Sumatera Utara 


\section{Pendahuluan}

Manusia ialah makhluk sosial yang selalu berinteraksi dan menjalin komunikasi dengan sesama manusia, sehingga tak jarang dalam komunikasi tersebut terdapat sebuah tuturan yang memiliki makna tersirat yang sukar dimengerti atau makna yang bukan sesungguhnya. Makna tersirat itu disebut dengan implikatur. Hal ini membuat lawan tutur akan berusaha memahami apa yang sebenarnya dikatakan oleh sang penutur agar tidak terjadi adanya kesalahpahaman. Sejalan dengan hal tersebut, Lubis (2012:98) menerangkan bahwa "Implikatur itu ialah bagaimana seorang mitra tutur berusaha menginterpretasi apa yang sebenarnya dikatakan oleh penutur.

Percakapan dalam pragmatik memaksa kita untuk memahami makna tersirat atau tersembunyi yang dituturkan oleh penutur agar tidak terjadi kesalahpahaman saat menangkap informasi yang disampaikan oleh penutur kepada mitra tuturnya. Percakapan sendiri biasanya melibatkan dua orang yang terbagi atas penutur dan juga mitra tutur atau bahkan lebih dari dua orang, tidak mungkin percakapan dapat berlangsung jika hanya ada satu orang sebagai penutur. Agar kita bisa mengerti dari makna tersembunyi yang ada dalam suatu tuturan bisa dipelajari melalui ilmu pragmatik yang membahas tentang implikatur percakapan. Implikatur percakapan sendiri diperlukan agar mitra tutur dapt secara jelas mengetahui maksud yang disampaikan oleh penutur, karena di dalam implikatur sering sekali kita temui bahwa penutur tidak secara langsung mengatakan maksudnya kepada sang mitra tuturnya. Pragmatik merupakan suatu ilmu tentang bagaimana bahasa itu digunakan untuk berinteraksi dalam suatu percakapan.

Mulyana (2005:11) Menerangkan bahwa fungsi implikatur dalam sebuah percakapan adalah sebagai jembatan penghubung antara apa yang sedang dicapkan oleh penutur dengan apa yang diimplikasikan atau diinterpretasikan oleh mitra tutur. Sehingga, dalam sebuah percakapan yang mengandung adanya implikatur terdapat suatu proses penafsiran yang tidak langsung pula. Dalam suatu situasi tutur, penutur biasanya sudah mengerti maksudnya, hanya saja terkadang penutur tidak mengungkapkan secara terangterangan karena memiliki berbagai alasan, hal ini memiliki tujuan agar apa yang sedang dituturkan tidak terlalu mencolok.

peneliti merasa sangat tertarik untuk melaksanakan penelitian mengenai analisis implikatur percakapan pada masyarakat Desa Serba Jadi, Sumatera Utara karena pada umumnya masyarakat ialah salah satu dari sekian banyak nya pengguna bahasa. Masyarakat umumnya lebih cenderung mengekspresikan diri di luar ruangan yang bersifat non formal ketimbang mengekspresikan diri di dalam ruangan yang bersifat formal. Sehingga terkadang ada bahasa yang memiliki makna tersembunyi yang tidak secara langsung dikatakan, sehingga terkadang mitra tutur akan berusaha untuk mengerti apa yang sedang dibicarakan agar tidak terjadi kesalahpahaman pada saat menangkap maksud dan juga informasi yang disampaikan oleh penutur. Berkenaan dengan penelitian ini, alasan paling mendasar yang melatarbelakangi peneliti untuk melakukan penelitian ini karena sebelumnya, peneliti pernah mendengar sebuah ungkapan yang mengandung implikatur yang di ungkapkan oleh masyarakat Desa Serba Jadi, Sumatera Utara tepatnya ketika saat itu peneliti sedang berkunjung ke salah satu rumah masyarakat yang ada di Desa Serba Jadi dan percakapan yang mengandung implikatur tersebut terjadi di sore hari, tepatnya hari Minggu, 15 Maret 2020 pukul 17.00 WIB. Peneliti sendiri 
merasa tertarik dengan implikatur yang terdapat dalam percakapan masyarakat tersebut, dan kemudian menjadikannya sebagai penelitian untuk menyelesaikan pendidikan.

Percakapan tersebut berbunyi,

A: Hei, ingatkah kamu dengan Hafni, teman kita sewaktu dulu di sekolah?

B: Iya, aku mengingatnya, lantas kenapa?

A: Ya, dia sekarang sudah menjadi orang!

Mengenai contoh di atas, penulis mencoba untuk memberikan sebuah gambaran mengenai kutipan percakapan yang mengandung implikatur. Kutipan contoh di atas mengandung implikatur karena, pada umunya situasi tersebut terjadi pada saat A dan B melangsungkan percakapan, apa yang dikatakan oleh penutur kepada mitra tutur memiliki makna yang sebenarnya berbeda dari apa yang penutur katakan. Dari contoh tersebut terdapat ungkapan "ya, dia sekarang sudah menjadi orang!" maksud dari kata orang di sini ialah bukan dia (Hafni) menjadi manusia karena pada hakkatnya yang dimaksud dia (Hafni) oleh si penutur A memang sudah menjadi manusia sejak ia dilahirkan, akan tetapi maksud dia (Hafni) sudah menjadi orang lebih merujuk pada makna bahwa "dia" sekarang sudah sukses dan kaya raya.

Penelitian tentang implikatur ini diharapkan sangat berguna bagi dunia pendidikan, khususnya di lingkungan mahasiswa Universitas Samudra, yang mana dengan adanya penelitian tentang implikatur percakapan seseorang dapat mengerti mengenai makna tersirat yang dikatakan oleh penutur kepada lawan bicaranya agar tidak akan terjadi salah paham saat menyaring suatu informasi yang telah diberikan. Penelitian tentang implikatur ini juga diharapkan khususnya kepada mahasiswa Universitas Samudra, agar dapat mengimplementasikan mengenai pembelajaran tentang implikatur agar tidak terjadi kesalahpahaman.

Penelitian mengenai analisis tentang implikatur sebenarnya sudah banyak dilakukan sebelumya, namun penelitian implikatur percakapan pada masyarakat Desa Serba Jadi, Sumatera Utara belum pernah dilakukan. Penelitian yang telah dilakukan oleh Afifah (2018) ia melakukan penelitian tentang implikatur percakapan dalam novel surga yang tak dirindukan karya Asma Nadia dan implikasinya terhadap pembelajaran bahasa di SMA, adapun tujuan dari penelitiannya ia mendeskripsikan implikatur percakapan antar tokoh novel menggunakan bentuk verbal dalam berimplikatur dengan memanfaatkan konteks dalam berimplikatur. Senada dengan itu, Nasution (2019) juga melakukan penelitian mengenai "Implikatur Percakapan pada Masyarakat Melayu Desa Lama," tujuan dari penelitian tersebut untuk mendeskripsikan wujud implikatur yang terjadi pada percakapan masyarakat Melayu Desa Lama di pasar tradisional. Penelitian yang berkaitan tentang implikatur percakapan juga sebelumnya sudah dilakukan oleh, Niatri (2016) tentang "Implikatur Percakapan Antartokoh dalam Film Marmut Merah Jambu karya Raditya Dika." Ia melakukan pendeskripsian terhadap jenis implikatur percakapan antar tokoh-tokoh yang ada di dalam film dan melakukan pendeskripsian terhadap fungsi implikatur percakapan antar tokoh-tokoh yang ada di dalam film Marmut Merah Jambu karya Raditya Dika.

Sejalan dengan itu, penelitian mengenai implikatur percakapan sebelumnya pernah dilakukan oleh, Zaleha (2019) mengenai implikatur percakapan dalam Film Rudy Habibie karya Hanung Bramantyo." ia mendesripsikan implikatur percakapan dalam 
film Rudy Habibie karya Hanung Bramantyo. Ia melakukan penelitian

melalui adegan dan percakapan para tokoh yang memainkan film tersebut. Senada dengan itu, Nurfachidaya (2021) juga melakukan penelitian mengenai implikatur percakapan berupa "Implikatur Percakapan dalam Wacana Stiker Angkutan Umum di Bertais." Penelitian itu bertujuan untuk mendeskripsikan bentuk-bentuk implikatur percakapan dalam wacana stiker angkutan umum di Bertais, serta mendeskripsikan strategi implikatur percakapan dalam wacana stiker angkutan umum di Bertais. Selanjutnya implikatur percakapan sebelumnya juga pernah dilakuan oleh, Sulistiani (2018) mengenai "Implikatur Percakapan dalam Wacana Humor Komik Kartun Sentilan Bung Sentil. Penelitian ini bertujuan, untuk mendeskripsikan implikatur percakapan sebagai penunjang humor yang terdapat di dalam wacana humor katun Sentilan Bung Sentil.

\section{Metodologi Penelitian}

Pendekatan dalam penelitian merupakan hal yang terpenting dalam sebuah penelitian. Pendekatan yang digunakandalam penelitian ini adalah pendekatan kualitatif, karena data yang didapat bersifat deskriptif. Menurut Sufardi dan Hakim (2015:237) bahwa "Deksriptif merupakan suatu pendekatan yang menyajikan, menjelaskan gambaran informasi berdasarkan hubungan antara fenomena yang diuji." Artinya, dalam penelitian ini sang peneliti mendeskripsikan dan juga memaparkan data dan menganalisis data yang mengandung implikatur di dalam percakapan masyarakat secara tidak terstruktur, fakta dan saksama mengenai kenyataan, sifat dengan apa adanya terhadap data yang disajikan.

Pendekatan dari penelitian ini berjenis kualitatif, disebut kualitatif karena data yang diperoleh dalam penelitian ini hanya berupa berupa deskriptif, dikatakan deskriptif karena penelitian ini dilaksanakan hanya berfokus pada suatu kebenaran dan kejadian pada percakapan masyarakat saja, Sugiyono (2019:19) juga menerangkan bahwa "Pendekatan kualitatif ini memiliki tiga tahap yang disebut tahap reduksi dan fokus, pada tahap ini peneliti mereduksi segala informasi yang telah diperoleh pada tahap pertama." Pada tahap reduksi ini, biasanya seorang peneliti mereduksi data yang sudah ia temukan untuk lebih memfokuskan penelitian pada masalah mana yang memang penting, dipakai dan sesuai dengan apa yang sebenarnya diperlukan.

Penelitian ini menggunakan suatu metode penelitian guna mendukung keberhasilan dalam penelitian yang sedang berlangsung, metode dalam penelitian ini berupa metode kualitatif. Sejalan dengan Sufardi dan Hakim (2015:157) Penelitian kualitatif merupakan penelitian yang bersifat deksriptif yang dalam sebuah pendekatannya biasanya dilakukan dengan cara induktif." Induktif sendiri merupakan pada sesuatu yang berpijak pada pengamatan fakta yang didapatkan berdasarkan hasil pengamatan yang ada di lapangan. Analisis data yang dilakukan dalam penelitian yang bersifat deksriptif juga juga bersifat induktif yaitu sesuai dengan fakta yang ditemukan seorang peneliti di lapangan. Penelitian ini berlokasi di Desa Serba Jadi, Kecamatan Sunggal, Kabupaten Deli Serdang yang bertempat di Provinsi Sumatera Utara. Desa Serba Jadi sendiri memiliki empat dusun yang terbagi atas Dusun I, Dusun II, Dusun III dan Dusun IV. Peneliti hanya menganalisis implikatur percakapan pada masyarakat Desa Serba Jadi dengan mengambil secara acak baik ibu rumah tangga, remaja dan juga bapak-bapak di setiap dusun yang ada di Desa Serba Jadi. Jumlah sumber data pada penelitian ini adalah sebanyak dua puluh lima orang

Analisis data adalah suatu proses yang sangat penting dalam menentukan suatu penelitian, Sugiyono (2019:244) Mengemukakan bahwa analisis data merupakan suatu tahap dari 
menyusun dan mencari secara tidak terstruktur atau beruntun mengenai data yang sudah didapatkan dari hasil wawancara, catatan lapangan dan juga dokumentasi, caranya adalah dengan mengumpulkan datadata yang sudah didapatkan tadi dalam kategori yang sesuai dengan jenis-jenis data dan kemudian peneliti akan memilih data mana yang kiranya penting dan selanjutnya penulis akan membuat sebuah kesimpulan agar lebih mudah dipahami.

\section{Hasil dan Pembahasan}

Dari hasil penelitian yang telah dilakukan oleh penulis, penulis menemukan beberapa data mengenai jenis-jenis implikatur dan juga maksud dari tuturan tersebut. Data yang telah penulis temukan merupakan data yang secara keseluruhan telah didukung oleh adanya suatu tindak tutur yang mendukung validnya suatu data-data yang telah penulis peroleh yang telah diperjelas dengan latar belakang terjadinya suatu situasi ujar dan juga terjadinya tindak tutur antar penutur dan juga mitra tutur. Penelitian berlangsung selama satu bulan di Desa Serba Jadi, Sumatera Utara yang mana penelitian ini bertempat di rumah warga yang ada di Desa Serba Jadi, kegiatan posyandu balita yang rutin dilaksanakan di Desa Serba Jadi, dan juga warung kopi yang ada di Desa Serba Jadi. Dari penelitian yang sudah dilaksanakan oleh penulis tersebut kemudian menghasilkan empat puluh dua percakapan, tetapi dari keseluruhan jumlah percakapan tersebut tidak semunya mengandung implikatur. Agar mempermudah penulis dalam melakukan analisis data yang telah didapat, kemudian penulis menyajikan hasil penelitian.

Implikatur percakapan yang ditemukan dalam percakapan masyakarat Desa Serba Jadi, Sumatera Utara pada kegiatan Posyandu, di rumah warga yang ada di Desa Serba Jadi, dan juga warung kopi yang ada di Desa Serba Jadi selanjutnya diklasifikasikan dan juga sudah diidentifikasi oleh peneliti. Implikatur percakapan kemudian diklasifikasikan oleh peneliti berdasarkan jenisnya menggunakan landasan teori dari para ahli seperti yang sudah di paparkan sebelumnya. Dengan adanya suatu pengklasifikasian dari jenis implikatur ini peneliti ingin memberi tahu bahwa suatu implikatur yang terdapat dalam suatu percakapan pasti berbeda dengan makna dari tuturannya. Setiap implikatur yang telah di temukan dalam percakapan masyarakat Desa Serba Jadi, Sumatera Utara dipaparkan sebagai berikut!

(a) Implikatur Konvensional

Implikatur konvensional sendiri merupakan suatu implikatur yang bersifat awet atau tidak sementara karena implikatur konvensional dapat terjadi walaupun tanpa adanya situasi ujar berupa percakapan, implikatur konvensional merupakan jenis konvensional ini terdapat suatu pesan yang diterima langsung dari arti kata yang didengar. Implikatur jenis konvensional ini sebenarnya tidak harus terjadi di dalam situasi pembicaraan dan juga ia tidak bergantung dengan konteks yang khusus untuk menginterpretasikan Mulyana (2005:12).

Implikatur konvensional juga merupakan suatu implikatur yang di dalam penggunaannya sehari-hari tidak bergantung dengan adanya suatu konteks yang melatarbelakangi terjadinya percakapan tersebut. Implikatur konvensional sendiri dapat diartikan secara langsung sesuai dengan makna kata yang didengar oleh mitra tutur dan sesuai dengan yang disampaikan oleh sipenutur. Pada implikatur konvensional sendiri, sifatnya lebih bertahan lama karena tidak bergantung dengan adanya situasi percakapan. Jadi setiap percakapan masyarakat yang ada di Desa Serba Jadi memiliki implikatur konvensional, berikut akan disajikan datanya.

Waktu

: Senin, 3 Agustus

2020

Pukul

: 10.00 WIB s.d 11.55

WIB

Tempat : Rumah warga 
NRL : "Mintaknya kan kayak gitu yakan, jambu ku kalau di pupuk cantik yakan."

JLN : "Semua kalau dipupuk cantik. Aku pun kalau di pupuk cantik juga."

Data tersebut merupakan suatu percakapan yang terjadi antara $\mathrm{J}$ dan $\mathrm{N}$. Pada percakapan tersebut terdapat suatu kalimat yang berbunyi 'aku pun kalau dipupuk cantik juga' termasuk ke dalam implikatur konvensional, karena pada kalimat tersebut memiliki makna bahwa bukan hanya buah yang cantik jika dirawat, seseorang yang melakukan perawatan juga pasti akan cantik. Implikatur konvensional ini bersifat awet, umumnya makna yang terdapat dalam ujaran yang mengandung implikatur konvensional biasanya lebih diketahui banyak orang. Implikatur konvensional sendiri bisa terjadi walaupun penutur dan mitra tidak dalam suatu situasi ujar berupa percakapan, implikatur konvensional ini lebih mengacu pada makna yang hampir semua orang paham dan mengerti maksudnya walaupun tidak dalam situasi ujar. Data tersebut mengandung sebuah implikatur konvensional yang ditandai dengan adanya kalimat yang dituturkan oleh N. Tuturan yang disampaikan oleh $\mathrm{N}$ masuk ke dalam implikatur konvensional karena, saat terjadinya percakapan.

Pukul : :10.00 WIB s.d 11.55 WIB

Tempat : Rumah warga

NRL : : "Kau kasih aku modal untuk pupuk kenapa Yun!"

SRW : "Ih, mau berapa kg pupuk nya?

STN : "Bilang aja ma beliau tu, tapi uang dia uang perempuan."

Data tersebut merupakan suatu percakapan yang terjadi antara $\mathrm{N}$, Yuni dan juga $\mathrm{T}$. Dalam percakapan tersebut, terdapat suatu kata berupa 'uang perempuan'yang dapat diartikan sebagai uang riba. Uang perempuan memiliki makna yang semua masyarakat paham dan mengerti apa maknanya. Uang perempuan dapat diartikan sebagai uang yang beranak atau yang biasa juga disebut dengan uang riba. Kata uang perempuan sendiri sering digunakan oleh masyarakat sekitar dan umunya sangat mudah dipahami maknanya. Uang beranak atau uang riba sendiri dapat secara langsung dipahami maknanya saat penggunaan kata tersebut bahkan tidak dalam situasi ujar dan tidak bergantung pada suatu konteks khusus untuk mengartikan maknanya. Masyarakat bisa langsung mengerti maksud yang disampaikan oleh penutur bahkan hanya dengan mendengar kata nya. Hal ini sesuai dengan pengertian implikatur konvensional yaitu maknanya dapat secara umum diketahui oleh banyak orang walaupun hanya mendengar dan tidak harus ada dalam situasi ujar.

Waktu : Jumat, 6 Agustus 2020

Pukul : 20.00 WIB s.d 21.00 WIB

Tempat : Rumah Warga

RNI : "Terakhir kita ngumpul kapan ya?"

HRI : "Itulah yang terakhir waktu Isra Miraj gak jadi tu."

Data tersebut merupakan suatu percakapan yang terjadi antara $\mathrm{R}$ dan juga $\mathrm{H}$, yang mana terdapat suatu kalimat berupa 'yang terakhir waktu Isra Miraj gak jadi tu' mengandung implikatur konvensional. Isra' Mirad jatuh pada hari Minggu, 22 Maret 2020, dan pada saat itu pemerintah melarang adanya kegiatan sosial berskala besar sehingga ditiadakannya acara peringatan Isra Miraj secara besar-besaran dan lebih membatasi jumlah orang yang hadir. Sehingga diantara mereka tidak dapat bertemu. Pada kalimat tersebut termasuk ke dalam jenis implikatur konvensional karena kalimat tersebut dapat dimengerti maknanya oleh masyarakat sekitar walaupun tuturan yang mengandung kalimat tersebut tidak sedang terjadi dalam sebuah situasi ujar.

(b) Implikatur Percakapan (Nonkonvensional)

Implikatur percakapan sendiri biasanya juga disebut implikatur nonkonvensioanal yang dalam sehari-hari dapat terjadi hanya pada 
saat adanya situasi tutur, sehingga memiliki makna yang bervariasi atau lebih banyak. Biasanya penafsiran mengenai apa yang sebenarnya dimaksudkan sangat berkitan erat dengan suatu konteks dan juga situasi saat terjadinya suatu percakapan. Sehingga hal inilah yang kemudian mengharuskan sebuah implikatur percakapan terjadi dalam sebuah situasi ujar dan sangat berkaitan pada konteks dan situasi saat terjadinya suatu percakapan. Sehingga hal inilah yang kemudian mengharuskan sebuah implikatur percakapan terjadi dalam sebuah situasi ujar (Mulyana,2005:13). Data mengenai implikatur percakapan atau implikatur nonkonvensional selanjutnya akan disajikan sebagai berikut!

Waktu : Senin, 3 Agustus 2020

Pukul : 11.00 WIB s.d 11.55 WIB

Tempat : Rumah Warga

NRL : "Dia gak bekawan kalo kaya."(Dia tidak berteman kalau kaya) IDP : "Lagi tutup ni pabrik."

Data tersebut merupakan suatu percakapan yang terjadi diantara $\mathrm{N}$ dan juga I. Secara keseluruhan daripercakapan tersebut mengandung implikatur percakapan atau implikatur nonkonvensional. Dalam percakapan tersebut sebenarnya $\mathrm{N}$ sedang menyindir kepada I.N mengatakan bahwa I jika sudah memiliki banyak uang tidak mau berteman lagi dengan mereka. Kemudian Inda mengatakan bahwa sudah tutup pabrik, sebagai respon dari apa yang dikatakan oleh N. Kalimat tersebut termasuk kedalam implikatur nonkonvensional karena, maksud dari percakapan tersebut hanya dapat dipahami oleh orang yang ikut terlibat dalam percakapan tersebut. Maksud yang dikatakan oleh penutur tidak akan dipahami oleh mitra tutur jika tidak ikut serta dalam situasi ujar. Dalam tuturan tersebut juga mitra tutur akan mengaitkan apa yang dikatakan oleh penutur dengan situasi dan juga konteks saat terjadinya percakapan tersebut untuk kemudian menafsirkan apa yang dimaksud oleh penutur. Dalam percakapan yang terjadi diantara $\mathrm{N}$ dan juga
I juga terdapat makna yang tersembunyi bahwa sebenarnya $\mathrm{N}$ ingin meminjam uang kepada Inda yang secara tidak langsung diungakpakan oleh N. Hal ini sesuai dengan pengertian implikatur nonkonvensional yang mengharuskan adanya situasi ujar. Dalam implikatur nonkonvensional ini juga memiliki makna yang lebih sementara karena berkaitan dengan adanya situasi ujar. Makna yang dihasilkan dari implikatur nonkonvensional juga umunya kebih bervariasi, karena penutur tidak secara gamblang mengatakan apa yang sebenarnya ia maksud.

Waktu : Senin, 3 Agustus 2020

Pukul : 11.00 WIB s.d 11.55 WIB

Tempat : Rumah Warga

SRW : "Yauda nanti kalian pesan ya nanti aku buat."

JLN : "Lagi covid ini"

Data tersebut merupakan suatu percakapan yang terjadi diantara $\mathrm{Y}$ dan juga $\mathrm{J}$. Percakapan tersebut termasuk ke dalam implikatur nonkonvensional karena pada percakapan tersebut, Y mengatakan kepada teman-temannya untuk memesan makanan yang nanti akan dibuat oleh $\mathrm{Y}$, dengan segera Juli mengatakan secara tidak langsung kepada $\mathrm{Y}$ yang berarti untuk tidak menjualnya dengan harga yang mahal karena lagi covid. Lagi covid sendiri menjadi menjadi penanda terjadinya suatu implikatur percakapan karena dalam percakapan di atas hanya mereka yang terlibat dalam percakapan saja yang mengerti makna dari apa yang sedang di katakan oleh Y. Dalam implikatur nonkonvensional biasanya akan terjadi hanya saat terjadinya situasi tutur berupa percakapan. Pada implikatur nonkonvensional seorang penutur akan lebih mengutarakan maksudnya secara tidak terang-terangan bahkan kadang penutur tidak secara gamblang mengungkapkan maksudnya. Biasanya dalam implikatur nonkonvensional memiliki banyak makna dan penafsiran mengenai maksud yang disampaikan mitra tutur biasanya sangat 
berkaitan dengan konteks dan situasi saat terjadinya percakapan.

Implikatur sendiri merupakan suatu cara untuk mengatakan sesuatu dengan cara tidak langsung dan memiliki makna tersirat di dalamnya. Dalam suatu pertuturan, penutur dan juga mitra tutur biasanya bisa secara lancar melakukan komunikasi karena mereka sendiri memiliki suatu kesamaan kondisi tentang sesuatu yang sedang dipertuturkan. Dalam suatu implikatur juga selalu melibatkan penafsiran maksud yang secara tidak langsung dalam sebuah komunikasi. Biasanya untuk menafsirkan maksud mitra tutur akan menghubungkan apa yang dikatakan oleh penutur dengan konteks dan juga situasi saat terjadinya percakapan.

\section{Simpulan dan Saran}

Terdapat dua jenis implikatur yang ada di dalam percakapan masyarakat yang ada di Desa Serba Jadi. Jenis implikatur itu terbagi atas implikatur konvensional dan implikatur percakapan atau yang bisa disebut juga dengan implikatur nonkonvensional. Implikatur percakapan terjadi hanya pada saat situasi ujar berupa percakapan dan sebaliknya implikatur konvensional dapat terjadi bahkan saat tidak dalam situasi ujar. Pada implikatur percakapan hanya dapat dimengerti oleh orang-orang yang terlibat dalam suatu percakapan. Sedangkan implikatur nonkonvensional dapat dimengerti walaupun tidak ikut serta dalam situasi percakapan tersebut.

Implikatur percakapan adalah implikatur yang dalam penggunaan sehari-hari terdapat hanya dalam suatu situasi ujar. Sedangkan implikatur konvensional memiliki keterbalikan dari implikatur percakapan, yang mana bisa terjadi walaupun tidak sedang dalam situasi ujar. Terdapat sebanyak empat puluh dua contoh implikatur dengan jenis yang berbeda-beda. Jenis implikatur yang paling banyak digunakan dalam percakapan masyarakat yang ada di Desa Serba Jadi, Sumatera Utara ialah implikatur percakapan, yakni sebanyak dua puluh tiga contoh implikatur percakapan. Sedangkan sisanya sebanyak Sembilan belas contoh merupakan implikatur konvensional.

Berdasarkan dari hasil analisis data dan juga kesimpulan yang telah dijabarkan sebelumnya, selanjutnya penulis akan menjabarkan saran sebagai berikut:

1) Penelitian tentang implikatur sudah selayaknya dilakukan karena dengan adanya suatu implikatur dapat dijadikan suatu referensi untuk lebih mengerti maksud yang dikatakan oleh penutur dan juga dapat menjadi referensi tentang mengetahui makna yang dituturkan oleh penutur.

2) Penelitian tentang implikatur ini juga sangat diharapkan dapat memberi manfaat bagi pembaca khususnya mahasiswa, penulis dan juga dapat dijadikan bahah penambah wawasan mengenai pragmatik, khususnya pemahaman tentang implikatur.

3) Penulis sangat berharap hasil dari analisis yang penulis lakukan dapat bermanfaat dalam penelitian selanjutnya yang serupa dengan yang penulis lakukan yakni terkait dengan kajian mengenai implikatur. 


\section{Daftar Referensi}

Alwi, Hasan, dkk. 2010. Tata Bahasa Baku Bahasa Indonesia. Jakarta: Pusat Bahasa dan Balai Pustaka.

Arikunto, Suharsimi. 2018. Prosedur Penelitian Suatu Pendekatan Praktik, Jakarta: PT. Rineka Cipta.

Azwardi. 2018. Metode Penelitian Pendidikan dan Sastra Indonesia. Banda Aceh: Syah Kuala University Press.

Lubis, A Hamid Hasan. 2015. Analisis Wacana Pragmatik. Bandung: Angkasa.

Lubis, Malan. 2012. Analisis Wacana. Jakarta: Halaman Moeka Publishinng.

Pembinaan Bahasa Kementrian Pendidikan dan Kebudayaan 2016. Kamus Besar Bahaasa Indonesia Edisi Kelima. Jakarta: Badan Pengembangan dan Pembinaan Bahasa.

Rahardi, Kunjana. 2008. Pragmatik Kesantunan Imperatif Bahasa Indonesia. Jakarta: Penerbit Erlangga 